\title{
An assessment of the potential and optimal method for biowaste energy production in Latvia
}

\author{
J. Pubule \& D. Blumberga \\ Institute of Energy Systems and Environment, \\ Riga Technical University, Latvia
}

\begin{abstract}
The European Union has set targets to minimise the deposited amount of biodegradable waste in landfills. European countries have to comply with the Landfill Directive and the Waste Directive to reduce landfilling of the biodegradable part of MSW to $35 \%$ within the next five to ten years. They also have to comply with the Renewable Energy Directive. According to the IPCC Guidelines for National GHG Inventories, the percentage of biowaste as a total of MSW composition is about 30\% in Eastern Europe. However, in Latvia, the assessed composition of waste varies greatly in different sources, and the biowaste fraction varies from $28 \%$ up to $58 \%$. In order to promote the development of renewable energy sources, the potential amount of biowaste must be assessed and, based on that, the optimal transformation into an energy method has to be found.

This paper presents an analysis of the possibilities to utilize biowaste for biogas production in Latvia, including biogas production from landfill gas and biogas production from biowaste by the method of anaerobic digestion. The analysis is based on a selection of criteria and methodology for the optimization of biowaste management and biogas production from biowaste, as well as on preliminary environmental impact assessments and cost-benefit analyses. The first results have shown that the optimal method for biowaste treatment and biogas production from biowaste in Latvia is anaerobic digestion. This optimization depends on certain conditions, e.g. distance from waste source to biogas production plant, energy potential of biowaste, efficiency of separate waste collection etc. The optimization target function includes engineering,
\end{abstract}


environmental, and economical parameters, which are applied to foresee the potential of biogas production.

Keywords: bio-waste, renewable energy, impact assessment, energy output, Latvia.

\section{Introduction}

The European Union has set targets to minimise the deposited amount of biodegradable waste in landfills. European countries have to comply with the Landfill Directive 1999/31/EC [1] and the Waste Directive 2006/12/EC [2] to reduce landfilling of the biodegradable part of MSW to $35 \%$ within the next five to ten years. They also have to comply with the Renewable Energy Directive 2009/28/EC [3]. According to the IPCC Guidelines for National GHG Inventories, the percentage of biowaste as a total of MSW composition is about $30 \%$ in Eastern Europe [4]. However, in Latvia, the assessed composition of waste varies greatly in different sources, and the biowaste fraction varies from $28 \%$ [5] up to $58 \%$. Thus, the potential amount of biowaste produced is uncertain.

There are different methods for biowaste utilization, e.g. biogas production, anaerobic digestion and the burning of composted materials. In order to promote the development of renewable energy sources, the potential amount of biowaste must be assessed and, based on that, the optimal transformation into an energy method has to be found.

During the last decades, the waste management system in Latvia has changed on a large scale. During the Soviet Union, there were more than 500 [6] waste dumpsites in Latvia. Nowadays, there are ten regional waste management regions in Latvia (see Fig. 1), each of them have a municipal waste landfill. The

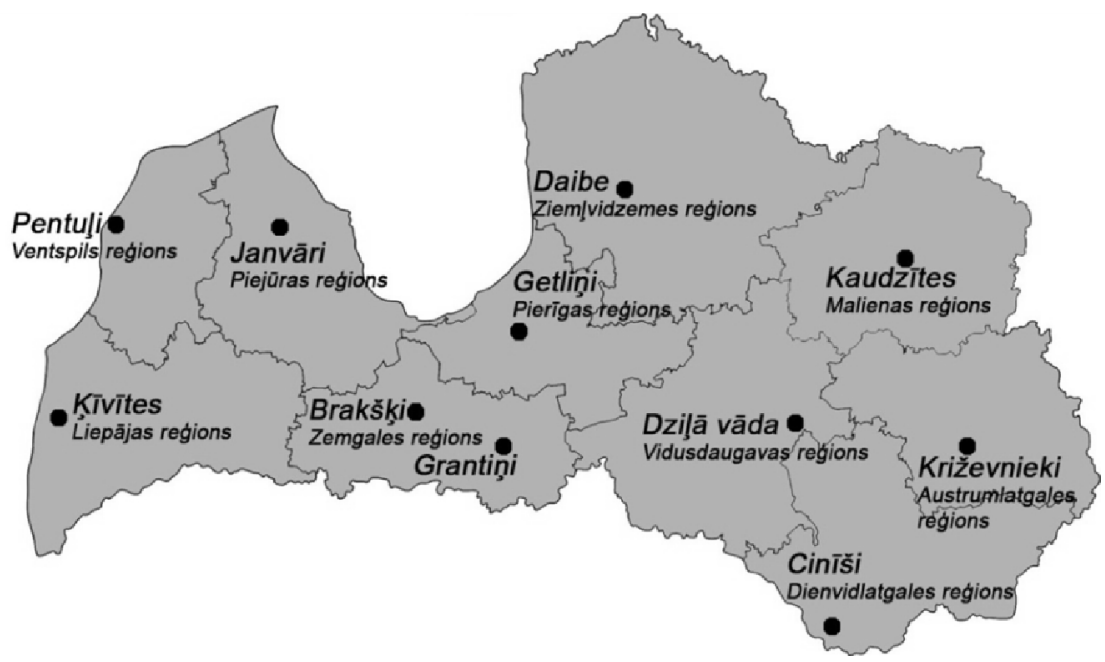

Figure 1: $\quad$ Waste management regions and landfills in Latvia. 
disposal of waste is allowed only in waste landfills; the last dumpsite was closed in 2011 .

The first waste management landfill was put into operation in 2005 (Greater Riga regional municipal waste disposal landfill "Getlini”"), the last of the 11 landfills "Dziḷā vāda" in the Vidusdaugava waste management region was put into operation in 2011.

\section{Waste management system in Latvia}

Waste management in Latvia is regulated by the Waste Management Law [7]. In accordance with this law, waste management in the state is carried out according to the Waste Management State Plan and the regional waste management plans. The waste management plan for 2006-2012 [8] envisages a series of measures to be implemented in the given time period regarding the biodegradable fraction which would improve the waste management situation in the country.

Looking back on the progress made, we may conclude that the measures have been partly fulfilled; for instance, the natural resource tax on biodegradable municipal waste disposal in landfills has been raised, and the local government binding regulations have been supplemented with a new section on biodegradable municipal waste management. At the same time, it should be noted that there are many unsolved issues hampering biodegradable waste treatment and its efficient use.

Currently, the largest part of municipal, and similarly, waste from trade and industrial enterprises and institutions, as well as separately collected waste, are deposited in landfills.

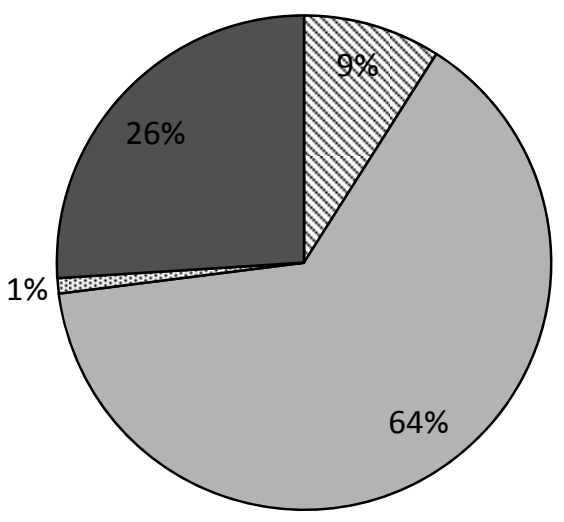

\$Recycled $\square$ Landfilled 团Imported $\square$ Exported

Figure 2: $\quad$ Management of waste in 2010. 
According to the statistical data, $64 \%$ of all the collected municipal and residual waste, including the biodegradable fraction and packaging, were deposited in the solid municipal waste landfills in 2010 in Latvia.

To minimise the deposited amount of waste, there will be changes in the waste management system in the coming years. The Waste Management Law requires that waste should be subject to treatment before it is landfilled.

\section{Existing biowaste management system in Latvia}

Latvia does not have a highly developed separate biowaste collection and treatment system. The only method mentioned in Latvian legislation for minimising the amount of biowaste and biowaste treatment is composting. During the development process of the waste management system, several solid waste disposal landfills in Latvia established composting facilities (see Table 1). The aim of the composting facilities was to minimise the amount of biowaste to be deposited in the country; however, practical experience shows that these composting areas are not being used to their full potential. Taking into consideration all of the above, it is necessary to introduce alternative methods for minimising the amount of biowaste deposited in landfills.

Furthermore, there are 10 composting plants, besides the compost plants in landfills, in Latvia. Mainly green waste such as leaves, grass, and branches are treated there. One of the plants is specified to the production of compost from sludge.

Table 1: Composting plants in landfills.

\begin{tabular}{|l|c|}
\hline Name & Compost plant $\left(\mathrm{m}^{2}\right)$ \\
\hline Križevnieki & 2000 \\
\hline Cin̄̄ši & 1050 \\
\hline Kaudzītes & 2000 \\
\hline Janvāri & 5038 \\
\hline Dziḷā vāda & 14000 \\
\hline Daibe & 5632 \\
\hline
\end{tabular}

\section{National goals regarding bio waste management}

In accordance with Directive No. 1999/31/EC on the landfill of waste (further in the text: Directive 1999/31/EC), waste is regarded as biodegradable if it is capable of undergoing aerobic or anaerobic decomposition, such as food waste, park and garden waste, paper, and paperboard. In compliance with the Directive No. 1999/31/EC, "municipal waste" means waste from households, as well as other waste, which, because of its nature or composition, is similar to the waste from households. 
In accordance with the Directive No. 1999/31/EC, Article 5, Paragraph 1, Member States shall set up a national strategy for the reduction of biodegradable waste going to landfills. This strategy should include measures to achieve the targets set out by the Directive. This will be accomplished by means of recycling, composting, biogas production and/or materials/energy recovery. Member States which in 1995, or the latest year before 1995 for which standardised EUROSTAT data is available, which put more than $80 \%$ of their collected municipal waste into landfills may postpone the attainment of the targets by a period not exceeding four years. Member States intending to make use of this provision shall inform the EC of their decision.

According to the Waste Management Law, biodegradable waste is any degradable waste from gardens and parks, households, restaurants, public catering establishments, retail premises selling food, kitchen waste, and other similar food production waste.

The Waste Management State Plan and regional plans set out measures, which promote the use of environmentally friendly materials manufactured from biowaste. These include the separate collection of biodegradable waste for recovery, composting, treatment, as well as measures for biodegradable waste treatment. Biologically degradable waste is composted in waste landfills or specially equipped places for composting biodegradable waste.

To meet the requirements of the Directive No. 1999/31/EC, the following amount of biodegradable waste may be disposed of in waste landfills in Latvia (Table 2).

Table 2: Amounts of biodegradable municipal waste to be landfilled.

\begin{tabular}{|c|c|c|c|}
\hline Year & $\begin{array}{c}\text { Estimated } \\
\text { production of } \\
\text { biodegradable } \\
\text { municipal waste, } \\
\text { tons }\end{array}$ & $\begin{array}{c}\text { Amount of } \\
\text { biodegradable } \\
\text { municipal waste to } \\
\text { be accepted for } \\
\text { disposal in the } \\
\text { landfill, tons }\end{array}$ & $\begin{array}{c}\text { Amount of } \\
\text { biodegradable } \\
\text { municipal waste not } \\
\text { acceptable to be } \\
\text { disposed of in the } \\
\text { landfill, tons }\end{array}$ \\
\hline 2010 & 607000 & 345000 & 262000 \\
\hline 2013 & 632000 & 230000 & 402000 \\
\hline 2020 & 691000 & 161000 & 530000 \\
\hline
\end{tabular}

\section{Potential of bio waste energy in Latvia}

During the research, an analysis of the biowaste amount and its characteristics was completed. The results show that the majority of biowaste, which can be used for energy production, is landfilled in Latvia.

From 11 landfills only 3 have landfill gas collection systems. This leads to the situation where almost all potential waste energy is unused. The amount of landfilled municipal solid waste during the five-year period between 2008 and 2012 decreased. This was mostly due to the economic crisis and a reduction in the number of inhabitants, and not to an increase of the recycling of waste. 
From 2008 till 2012 the amount of landfilled municipal solid waste decreased by approximately 30\%, from 64688 tonnes in 2008 till 431790 tonnes in 2012 . According to previous research $[5,10]$ on the composition of municipal solid waste, the percentage of biowaste is $28-36 \%$ of the total municipal solid waste mass. Therefore, an average of $30 \%$ biowaste was used during the calculations. The amount of biowaste, which could be separated from municipal solid waste, was 219411 tonnes in 2008 and 151127 tonnes in 2012.

In Figure 3, the amount of landfilled waste, including municipal solid waste biowaste, together with green waste and sludge is shown.

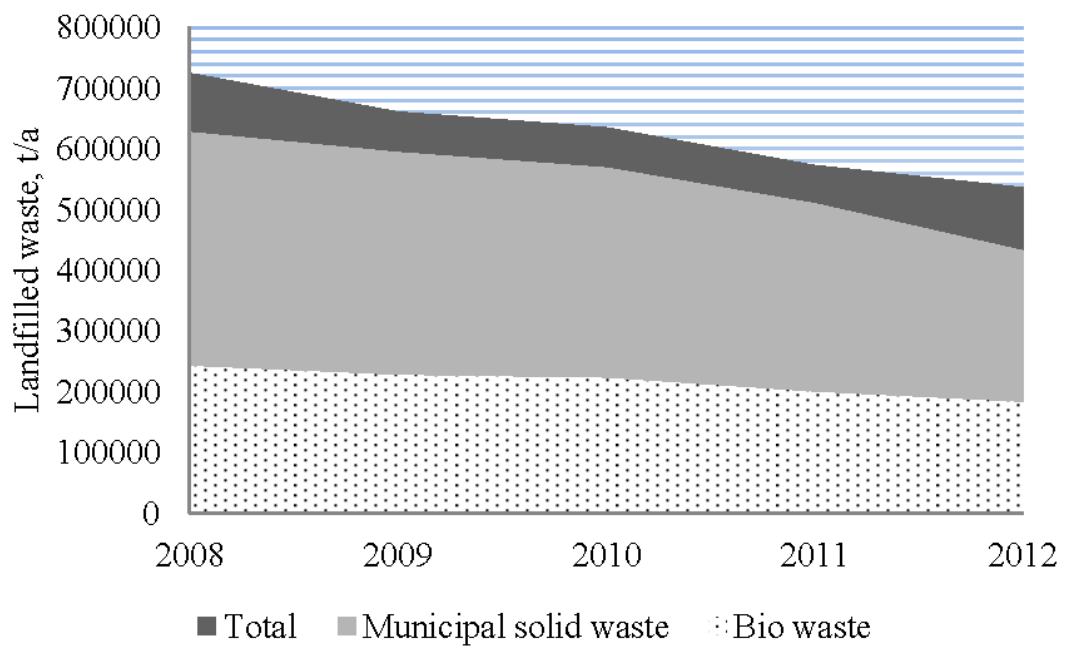

Figure 3: $\quad$ Amount of landfilled waste in Latvia, 2008-2012.

The figure shows a decrease in the amount of landfilled municipal solid waste, but at the same time the amount of landfilled biowaste, which includes green waste, sludge and biowaste from kitchens and enterprises, has changed only slightly during the last five years.

Figure 4 shows the ratio between recycled and landfilled biowaste by years.

The figure shows that the amount of recycled biowaste is increasing very slowly. Therefore, it is necessary to find better methods for biowaste management in Latvia.

\section{Scenarios for bio waste energy production}

During the upcoming years, biological-mechanical treatment [11] equipment will be installed in all Latvian landfills. Therefore, it is necessary to find an optimal solution for biowaste energy production. 


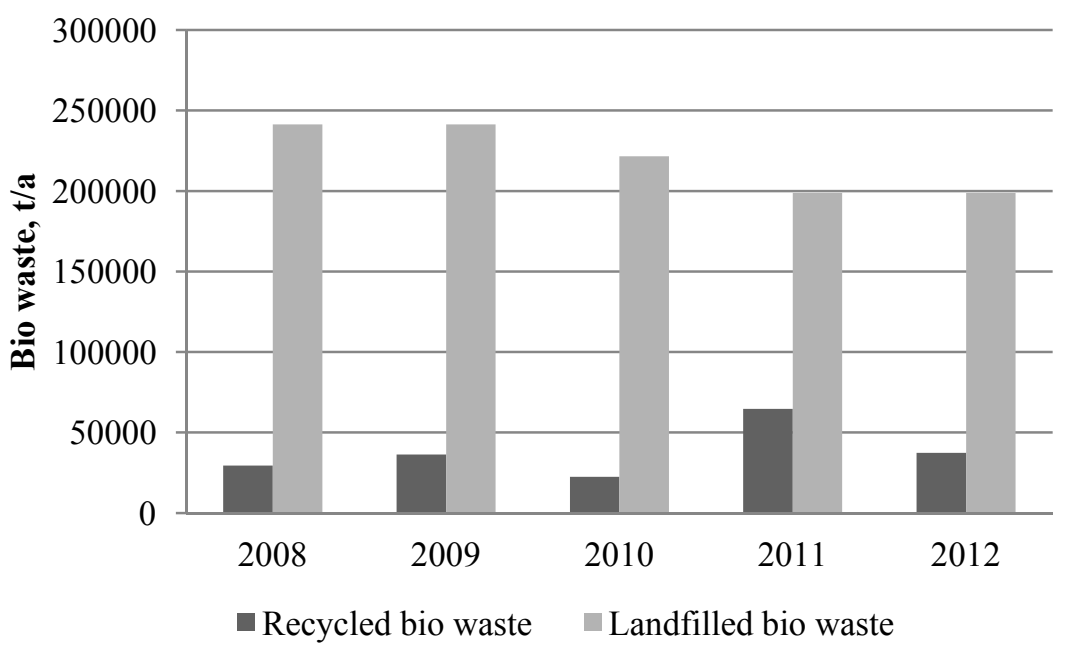

Figure 4: $\quad$ Amount of landfilled and recycled bio waste.

Five scenarios are explored for biodegradable waste treatment in Latvia:

1. Baseline scenario.

2. Composting scenario.

3. Centralised biowaste anaerobic fermentation with a high content of dry matter.

4. Centralised biowaste anaerobic fermentation with a low content of dry matter.

5. Incineration scenario.

All scenarios use the existing waste collection and transport system for unsorted municipal waste, and the regional waste landfills. In addition, the gradual implementation of separate biodegradable waste collection is proposed for legal persons and for inhabitants. For the production of cleaned material for biowaste treatment, it is necessary to develop a separate collection of organic waste in the future. In the medium term, unsorted municipal solid waste collection and further biological-mechanical treatment may be considered as the most viable economically. The most essential obstacles for the introduction of separate biowaste collection in the medium term (till 2020) are the following: a payment increase for waste producers, waste managers' additional expenses for the installation of new separate collection containers, and an increase in waste collection transport costs.

\subsection{Baseline scenario}

The "baseline scenario" provides biological-mechanical pre-treatment of unsorted waste. In the baseline scenario, the result of the pre-treatment would be a biowaste inert waste mix fraction, which is composted in the existing 
composting facilities, and the achieved material is used for placing in the landfill cell as an intermediate cover.

The given biowaste treatment process does not provide for the efficient minimisation of greenhouse gas emissions [12], energy is not recovered, and the treatment process does not provide maximum economic added value. No use of nutrients is possible.

Landfill gas could be energetically used, but energy output is low.

\subsection{Composting scenario}

The composting scenario provides for the composting of biowaste with a high content of lignocellulose. This scenario could be applicable for green waste or small facilities (further use of compost for greening, recultivation of lands, pits, scuffles, organic farming, decorative improvement, sport areas, fields. Composting is a common practice in many cases, as well, this occurs in Latvia and all over Europe. The environmental benefit for this scenario is a high-value end-product [13] and a closed nutrient cycle.

The amount of green waste, which can be composted using this method, is shown in Figure 5.

The amount of green waste is about 15,000 tonnes a year. It is recommended to use this scenario only for green waste since compost produced in Latvia is currently not required, and this scenario has no energetic output.

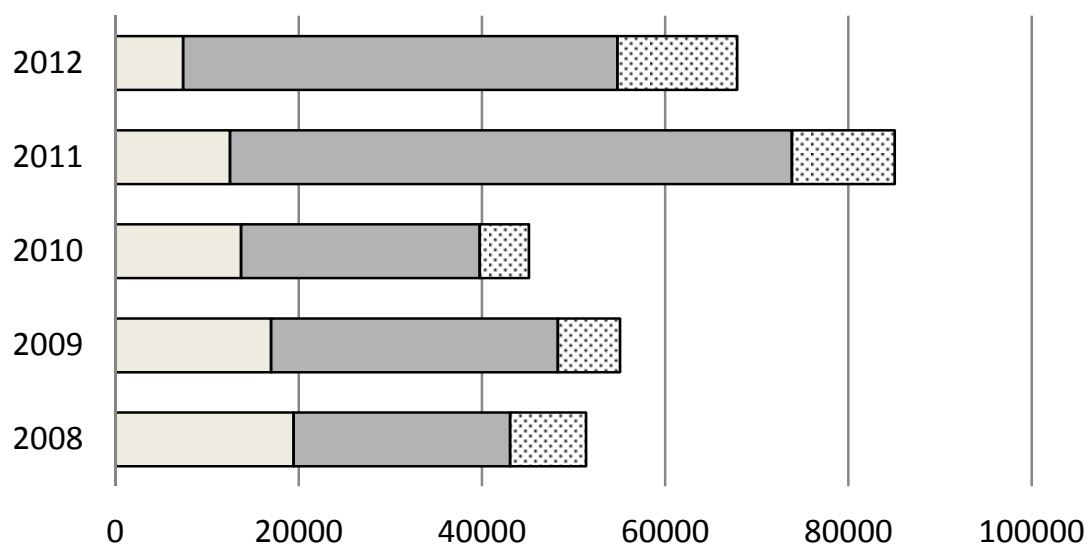

$\square$ Bio waste $\square$ Sludge $\quad$ Green waste

Figure 5: $\quad$ Composition of waste from 2008 till 2012.

\subsection{Centralised bio waste anaerobic fermentation with high content of dry matter}

As a result of biowaste anaerobic fermentation with a high content of dry matter the amount of waste organic dry matter decreases and, as a by-product, biogas is 
generated. Initially, the generated biogas may be used in biogas co-generation facilities for energy and heat recovery or for transportation purposes after biogas purification and compression. This scenario ensures a high energetic output from one side and a high-value end-product and closed nutrient cycle (digested material) from the other side. To implement this scenario, non-technical support is needed in Latvia. This scenario can be applied for almost all biowaste, which is separated from municipal solid waste, approximately 150,000 tonnes per year. In this scenario, additional financing for the investment costs is required. The introduction of this scenario would increase the waste management tariff by approximately $30 \%$.

\subsection{Centralised bio waste anaerobic fermentation with low content of dry matter}

In the future, it will be necessary to develop and implement a state waste management policy for separate biowaste collection. The expenses to consumers and waste managers may substantially increase while it is not predictable how the total amount of the collected waste increases.

From the technological point of view, the contents of waste from households and biowaste similar in composition contains a high content of dry matter (30-40\%), variable composition, different packaging and other waste mix, which all adds to the cost of its preparation process for anaerobic digestion in fermenting facilities.

In order to use such digestate or compost in agriculture, stringent waste composition control is necessary, as well as pasteurisation before its input into fermentation facilities, so as to provide for the elimination of pathogenic organisms [14].

The implementation of this scenario requires additional financing for investments: containers, waste collection vehicles and equipment. The approximate amount of investments for a separate biowaste collection system implementation throughout the whole country is 3,215,000 Euro.

\subsection{Incineration scenario}

Currently, there are no special waste incineration plants in Latvia. At the same time, refuse derived fuel (RDF) is used for the production of cement in one cement plant. In the upcoming years in the Baltic States Lithuania and Estonia, 7 waste incineration plants will start to operate with a total capacity of 815,000 tonnes of RDF a year [15]. Therefore, a portion of waste produced in Latvia could be burned in waste incineration plants in Estonia or Lithuania. A part of the biowaste, after anaerobic digestion, could be incinerated to produce electricity in the case that it will not be necessary to use digested biowaste to cover landfills.

\section{Conclusions}

The existing biowaste management system is ineffective; therefore, other solutions regarding organic waste should be sought. 
Four of the five previously mentioned biowaste management scenarios can be used for biowaste treatment in Latvia. Anaerobic digestion provides the biggest energetic output from biowaste management. Taking into account the financial situation in the country, existing plans for waste management development in the country, and the possibility of inhabitants to pay for waste management, the best solution in the mid-term (till 2020) is centralised biowaste anaerobic fermentation with a high content of dry matter. However, in the long-term (after 2020) it will be necessary to develop a system for the separate collection of organic waste with further treatment using anaerobic digestion with a low content of dry matter. Composting should be used only for treating green waste, which contains lignocellulose since the composting method has no energetic output.

\section{Acknowledgement}

This work has been supported by the European Social Fund within the project "Support for the implementation of doctoral studies at Riga Technical University".

\section{References}

[1] Council Directive, 1999/31/EC. Council Directive of April 26, 1999 on the landfill of waste, Official Journal L 182, July 16, 1999.

[2] Directive 2006/12/EC of the European Parliament and of the Council of 5 April 2006 on waste, Official Journal of the European Union L 114/9, April 27, 2006.

[3] Directive 2009/28/EC of the European Parliament and of the Council of 23 April 2009 on the promotion of the use of energy from renewable sources and amending and subsequently repealing Directives 2001/77/EC and 2003/30/EC, Official Journal of the European Union L 140/16, June $5,2009$.

[4] The Intergovernmental Panel on Climate Change, "Guidelines for National Greenhouse Gas Inventories. Volume 5: Waste”, Prepared by the National Greenhouse Gas Inventories Programme, edited by Eggleston, H.S., Buendia, L., Miwa, K., Ngara, T. and Tanabe, K., available at: http://www.ipcc-nggip.iges.or.jp/public/2006gl/vol5.html (accessed on 17 September 2011).

[5] Purmalis, I., Vircavs, M. Waste management in Latvia. Ecological Chemistry and Engineering, 18 (2), 2011.

[6] Aleksic, D., Reichel, A. Municipal waste management in Latvia, 2013.

[7] Waste Management Law: Republic of Latvia Law // Official journal of RL “Latvijas Vēstnesis”, No. 183 (4375), 17.11.2010.

[8] Ministry of Environment and Regional Development, The National Waste Management Plan 2006-2012, 2005.

[9] Ministry of Environment and Regional Development, The National Waste Management Plan 2013-2020, 2012. 
[10] Arina, D., Bendere, R., Teibe, I. Pre-treatment Processes of Waste Reducing the Disposed Amount of Organic Waste and Greenhouse Gas Emission. The ISWA world solid waste congress, Florence, 2012.

[11] Esmaeil, H., Yusoff, S., Nouri, J., et al. Life cycle assessment of biological-mechanical treatment in solid waste management. Scientific Research and Essays, 7(5), 2012.

[12] Thanh, N.P., Matsui, Y. An evaluation of alternative household solid waste treatment practices using life cycle inventory assessment mode. Environmental Monitoring Assessment, 184, 2012.

[13] Füleky, G., Benedek, S. Composting to Recycle Biowaste. Sociology, Organic Farming, Climate Change and Soil Science Sustainable Agriculture Reviews, 3, 2010.

[14] Albihn, A. Recycling Biowaste - Human and Animal Health.

[15] Problems. Acta Veterinaria Scandinavica, 95, 2001.

[16] Moora, H., Voronova V., Uselyte R. Incineration of Municipal Solid Waste in the Baltic States: Influencing Factors and Perspectives. Waste to Energy. Green Energy and Technology, 2012. 